\title{
QUEEN'S
UNIVERSITY
BELFAST
}

\section{Citizenship, entitlement, and autochthonic political projects of belonging in the age of Brexit}

Vieten, U. M., \& Yuval-Davis, N. (2018). Citizenship, entitlement, and autochthonic political projects of belonging in the age of Brexit. In S. G. Ellis (Ed.), Enfranchsing Ireland?: Identity, citizenship and state (pp. 70-80). Royal Irish Academy. https://www.ria.ie/enfranchising-ireland-identity-citizenship-and-state-0

\section{Published in:}

Enfranchsing Ireland?

\section{Document Version:}

Peer reviewed version

Queen's University Belfast - Research Portal:

Link to publication record in Queen's University Belfast Research Portal

\section{Publisher rights}

Copyright 2019 Royal Irish Academy. This work is made available online in accordance with the publisher's policies. Please refer to any applicable terms of use of the publisher.

\section{General rights}

Copyright for the publications made accessible via the Queen's University Belfast Research Portal is retained by the author(s) and / or other copyright owners and it is a condition of accessing these publications that users recognise and abide by the legal requirements associated with these rights.

Take down policy

The Research Portal is Queen's institutional repository that provides access to Queen's research output. Every effort has been made to ensure that content in the Research Portal does not infringe any person's rights, or applicable UK laws. If you discover content in the Research Portal that you believe breaches copyright or violates any law, please contact openaccess@qub.ac.uk. 
Citizenship, entitlement and autochthonic political projects of belonging in the age of Brexit

Nira Yuval-Davis, University of East London \& Ulrike M Vieten, Queen's University Belfast

\section{Abstract:}

The chapter examines some of the reasons' different sections of the British society, particularly in England and in Wales, have voted for Brexit and link it with recent developments with the ways people and governments are being engaged in racialized political projects of belonging. The overall argument is that Brexit should be analysed in the context of people and governments' reactions to the global and local double crisis of governability and governmentality. The recent rise of populist politics among British people, including some of its racialized minorities, needs to be seen on the background of the British 2014 \& 2016 Immigration Acts which established 'everyday bordering' as primary technology of controlling diversity and discourses on diversity, undermining convivial pluralist multi-cultural social relations. In these processes, border guarding is added to citizenship duties, and the boundaries of social rights are being shifted from the boundaries of civil society towards the boundaries of political citizenship.

\section{Introduction:}

The majority vote of the British people to leave the European Union in summer 2016 ('Brexit') has caught almost everyone by surprise - the stock market that bet on the UK remaining in the EU, the British government - as well as the Labour opposition - which did not even bother to prepare contingency plans in case of Brexit and even the leaders of the Brexit camp, like Nigel Farage and Boris Johnson prepared their defeat speeches rather than that of their unforeseen success.

A thorough analysis of the Brexit situation, e. g. the reasons the previous British PrimeMinister, David Cameron, decided to go ahead with the EU referendum in the first place, the ways the campaign developed and the role the British media played in it, as well as the effects this referendum is going to have on European and global politics, economy and society, will no doubt occupy social scientists for a long time to come.

The whole membership of the UK in the EU has been based on this kind of ambivalence between being part of Europe and not being part of Europe, and it is not just a question of how British people saw their political community. In Brexit it was a British people's 
ambivalence between the construction of the political community with a nostalgia towards empire and this has been important not just in the vote of the white working class people, but also of settled people who come from the ex-empire of the UK.

Some of these ambivalences have a long history, which is shaped by colonial and commercial cosmopolitanism (Vieten 2007; 2012). Even before the EU referendum was on the horizon, there was an unease with some of the civic and political trajectories of Continental Europe which contradicted Britain's primarily liberal market interests (ibid). Since the 1980s Thatcher and Reagan years, with liberal capitalism in power, and later on waiving in EU, austerity', the idea of any social integration beyond mere economic integration of the European bloc has been a contested issue and limited to a large extent to a more left-wing route (Schiek 2012; 2016).

Britain, as a longstanding 'reluctant EU lover' projected some of its post-2008 financial (economic) and social class (structural poverty) crisis as a failure of Europe and blaming EU institutions, regulations and the transnational 'Brussels' elite: The rise of racist attacks in the aftermath of the June 2016 referendum, and the 'special friendship' intonation of some leading Westminster politicians appeasing to the New US governance style and their white Western supremacy tell a story of worse to come.

In this chapter we are going to examine some of the ways Brexit embodies longer processes of the reconstruction of British citizenship. If T. H. Marshall (1950, 1975, 1981) defined citizenship 'as full membership in political communities' which encompasses political, civil and social rights as well as responsibilities, we are seeing a process in which border guarding is added to citizenship responsibilities and the boundaries of the political community are being largely redrawn to those who hold British state citizenship rather than those members of civil societies who live in Britain and are holding a variety of EU and other state citizenships. This also signified a collapse of British multiculturalism policy and links into the wider context of the securitisation of visible religious minorities, e. g. Muslim communities, as will be explained later in the chapter. The overall argument here is that Brexit should be analysed in the context of people and governments' reactions to what Nira Yuval-Davis calls elsewhere (2012) 'the double crisis of governability and governmentality'. Particularly significant here are the turning of many traditional Labour voters, especially in North England, to vote UKIP (United Kingdom Independent Party; the party that called for Britain to leave the EU) and the fact that among those who voted for the UK 
to leave the EU have been quite a few members of racialised minorities of settled immigrants, mostly from countries that used to be part of the British Empire. These two populist responses need to be seen on the background of the British 2014 \& 2016 Immigration Acts which, as Nira Yuval-Davis and her colleagues Georgia Wemyss and Kathryn Cassidy (2016) argue have established the technology of 'everyday bordering' as primary technology of controlling diversity and discourses on diversity, which is aimed to undermine convivial pluralist multi-cultural social relations which were the aim of previous technologies of control of British governments in previous decades.

The structure of the chapter will be the following:

Firstly, we explain briefly the double crisis which provides the structural background to contemporary forms of racialisation.

Secondly, we turn to what Yuval-Davis et. Al. (2017, forthcoming) call 'everyday bordering', as a reactive government technology of control which in its turn is contributing, as well as being affected by, autochthonic political projects of belonging. These political projects of belonging, which we see as the predominant form of contemporary racialisations. In the conclusion, the chapter draws together the main arguments and the social and political dynamics of Brexit, also for the Island of Ireland.

\section{The double crisis}

Neo-liberal globalization emerged in a period of global optimism after the fall of the Soviet Union and the supposed victory ('end of history' to quote Fukuyama, 1992) of democracy, freedom and a mainstream discourse of a cosmopolitan world (e.g. Cheah et Al. 1998; Archibugi et. Al. 1998; Beck 2003; Beck \& Grande 2007) in which social, national and state borders were on the wane. Less than twenty years later, we find ourselves in a world in which deregulation and globalization have been used to enhance global social inequalities, within as well as between societies', and a deepening systemic signs of neoliberalism's multi-faceted systemic global political and economic crisis, a crisis that is central to relationships between states and societies and to constructions of subjectivity and thus needs to be seen as a double related crisis of both governability and governmentality (Yuval-Davis, 2012). Now what do we mean by this double crisis of governability and governmentality? When we are talking about globalisation, we are not talking just about globalisation; we are talking about neo-liberal globalisation. What we see in this new liberal globalisation means that power and the accumulation of 
resources of the biggest multinational corporations are more than ten times altogether the accumulated resources that all states in the world have altogether (e.g. Cohen 2007; also see Guardian Panel on Capitalism, 16.4.12, link?). This means that the relative power of governments to govern, rather than to negotiate their powers with the interest of multinationals has become weaker. Moreover, as a result of that and privatisation of the welfare state has been part and parcel, not just of the welfare part. We know even that the prison service and part of the military even are being privatised (e.g. Pattison, 2010) So as a result of that and we saw it very clearly at the crisis in 2008 with the banking crisis, there is such entanglement between the private sphere and the public sphere, that there is no way that one can claim the public sphere without for example salvaging the banks, otherwise the public sphere would have been collapsing. While the European Union provides an alternative form of multi-level and supranational governance (Sweet \& Sandholtz 1997) its applicability and advocacy in different EU countries has been shrinking for decades (Eichenberg \& Dalton 2007). Benhabib (2004, 13) has pointed out more than 12 years ago that 'the EU is caught in contradictory currents which move it towards norms of cosmopolitan justice in the treatment of those who are within its boundaries, while leading it to act in accordance with outmoded Westphalian conceptions of unbridled sovereignty toward those who are on the outside...'the negotiation between insider and outsider status has become tense and almost warlike.'

This contradictory road of the European project itself in terms of normative frames, lack of legal cohesion and social inclusion has helped to undermine the EU's claim of good governance. (See also Schierup \& et. Al., 2006)

The results of the UK EU referendum in June 2016 has shown how the distrust of the EU brought a majority of the population across the UK, to vote to leave the EU. Northern Ireland and Scotland voted differently than the majority of people in England and Wales and the regional divisions highlighted by this distinctive view might also pose new frictions to the concept and claim of the United Kingdom of Great Britain and Northern Ireland, in the near future. Consolidating the popular vote of BREXIT in June 2016, the parliamentary backing by a majority of MPs in the House of Commons on the $1^{\text {st }}$ of February, means the UK government can go ahead triggering Art. 50 of Lisbon Treaty. ${ }^{i}$ However, through the rejection of a future political alliance with Europe and the project of regional governance and polity integration, the UK enters a new stage of 
insecurity and changed policy identifications, including new challenges to governmentality.

The 2008 economic crisis has shown that the growing entanglement and dependency not only of local and global markets but also of local private and public institutions has meant that various states have been forced to bail out banks and large corporations for fear of total economic collapse; even though the capacity of state agencies to enforce regulation on that same private sector is extremely limited. In the post-2008 international banking crisis debates, the slogan 'profits are privatised, and debts socialized ${ }^{\text {ii }}$ went viral.

As Richard Murphy (2011) and others have pointed out, as a result of state policies of deregulation, and the increasing privatisation of the state (including the many forms of so-called public-private partnership), in many cases it is no longer easy to draw a clear differentiation between the public and the private. Whole locations and domains which used to be part of public space - from schools to shopping areas - are no longer public, but are rather owned by, or leased for a very long period to, a private company or consortium of companies. The shift from a civic and political notion of citizenship to that of a citizen as a consumer (Bauman 2007) has been silent, but effective. For example, you get compensation if the train is late for three hours, but you don't have a say whether the train should be privatised or not. Though you only get the compensation if acting assertively, or otherwise having the financial means to go to court and trial the privatised train companies. London, and the planning and delivery of the Olympics 2012, is a case in point: Richard Murphy (2011) and others developed the notion of contract capitalism; in the end, the decisions how to run the Olympics were privatised. In preparation of the 2012 London Olympics there were about a hundred-and-forty contractors engaged, further outsourcing their delivery to other contractors. So any issue around there, for example, appropriation of public, what people thought that they were the common or public sphere, were not anymore part of the public debate because it was part of the contract with particular private companies. Moreover, since the 1990s, the proportion of global assets that are in foreign ownership continue to rise. Furthermore, the sphere that is regarded as part of 'national security', and thus as off limits for foreign ownership, is also continuously shrinking. A French company now owns a British energy company, the Chinese are building its nuclear power station and British airports are owned by a Spanish company. As Will Hutton (2012) pointed out in a Guardian 
public debate (Guardian Panel on Capitalism, 16.4.12; see also the Independent, 'Who Owns Britain: Watchdog launches first UK stock-take', 15.5.10.), states are becoming small fry in comparison with international markets. The GDPs of all the states in the globe when added together total about 70 trillion dollars, while the total amount of money circulating in the global financial markets is between 600 and 700 trillion.

But this is not simply a matter of statistics and numbers. Or, to put it differently, this quantitative phenomenon is simply one aspect - though a very significant one - of the problems that result from the basic legal relationship that pertains between corporations and states, whereby companies have the status of fictional citizens which enables the people who run them - through their 'Ltd' affix - to escape responsibility for the results of their corporations' actions, while retaining their ability to control the funds. In this era of increasing globalisation, the ability on the part of companies - and the people who run them - to change locations, base themselves in tax havens, and escape having to bear the social, economic, environmental and other consequences of their actions, is becoming ever clearer - in the Global North as well as the Global South; and the rhetoric of governments on budget days has very little impact on their activities. Moreover, while states have been forced to bail out banks to avoid major economic collapse (given the growing lack of differentiation between private and public financial sectors), states themselves - such as Greece, Ireland and others - have found themselves forced to cut their own budgets severely, against the interests of their citizens.

Thus, the crisis of governability is a result of the fact that in the time of neo-liberal globalisation, governments cannot anymore primarily represent the interests of their citizens. The crisis of governmentality follows this crisis of governability, because when people feel that their interests are not pursued by their governments - even the most radical ones, like in Greece - they feel disempowered and deprived. After a while they also stop buying the neo-liberal ideology which tells them that it is their responsibility if they fail to be healthy and wealthy, to provide for their families and become part of the incredibly rich and famous. Saskia Sassen (2015) has argued that, as a result of neoliberal globalisation, rather than experiencing an overall weakening the liberal state has changed internally: executive powers have strengthened at the expense of legislative branches. This is partly as a direct result of the privatisation of the state, whereby a substantial number of the regulative tasks of the legislature have been lost; and it is partly because it is the executive branch that virtually exclusively negotiates with other 
national and supranational governance executives (such as the EU, the UN, the World Bank, the World Trade Organisation), and with private, national and especially transnational corporations.

This is an important observation, which offers some explanation of the governmentality crisis: because of the increasing power of the executive, there is growing disenchantment and alienation from the state on the part of citizens, who accordingly begin to refrain from internalising and complying with the neoliberal state's technologies of governance. This disenchantment is particularly important in countries where voting in national elections is solely for the election of members of parliament, rather than also for the head of the executive (although, as the recent local elections in the UK and Germany have shown, it can be evident there as well). At the same time, in parliamentary democracies the right to rule the state is dependent on formal endorsement by the electorate of particular parties; this is what gives the state legitimacy. Hence the growing worry of governments at the lack of involvement of the electorate in these processes.

The growing securitisation and militarisation of the liberal state is directly related to the fear within ruling elites that arises from this crisis of governmentality. The forms of resistance to this crisis, however, vary widely - depending on people's intersected positionings, identifications and normative values: they can be more or less violent, more or less radical, more or less guided by primordial as opposed to cosmopolitan value systems.

This is the time in which it becomes very easy to shift responsibility to those who 'do not belong' - the migrants or anyone else who have different look, accent, culture and religion.

On this background, those of us who have been working on issues of racism, nationalism and ethnic relations, find ourselves with new challenges with the combined emergence of everyday bordering as a technology of control of diversity and discourses on diversity and autochthonic populist politics of belonging in a growing number of places on the globe, to produce new forms of intersectional racist practices. 
Barth (1998) and others following him, have argued that it is the existence of ethnic (and racial) boundaries, rather than of any specific 'essence' around which these boundaries are constructed that are crucial in processes of ethnocisation and racialisation. Any physical or social signifier can be used to construct the boundaries which differentiate between 'us' and 'them'.

The Irish 2004 Citizenship referendum, for example, changed ius soli (the republican territorial notion) to ius sanguinis (the ethno-national notion), and opened the door ideologically to endorse this form of ethno-national boundary drawing.

The situation in Northern Ireland is different though to a state focused ethno-national imagination as the ongoing political division into two as distinctively perceived ethnonational-religious groups (e.g. The Catholic/Republican; the Protestant/ Loyalists) means that there is not (yet) an established imagination of one cohesive and uniting political community that constructs itself against the Other. Sectarianism (see for details Bell \& McVeigh, 2016) and the political framework of consociationalism (McGarry \& Leary, 2006; see for a critical comparative debate Angelov, 2004) ${ }^{\mathrm{iii}}$ shape how everyday life as well as policy and governance is organised in Northern Ireland. This is not to say that racialising of Others, and hate crimes (Jarman \& Monagh 2003) are not an issue; 'othering', however, rather has to be seen and analysed differently as there is an Other historically constructed and established in the visibility of the 'other' Christian' ethnonational collective in the Northern Irish society ${ }^{\text {iv }}$.

Current post-Brexit debates on the Isle of Ireland asking among others, for a special status of NI, the January 2017 collapse of the Stormont two party- sharing system (DUP/ Arlene Foster and Sinn Fèin/ Martin McGuinness) ${ }^{\mathrm{v}}$, but also the ways new generations, 'shared' education and further processes of normalisation will affect living together of different communities, might change notions of citizenship and national boundary drawing, in future.

Alongside this form of a sectarian state of society, usually, state borders are but one of the technologies, used to construct and maintain imagined political community boundaries.

It is for this reason that contemporary border studies largely refer to 'borderings' rather than to borders, seeing them more as a dynamic, shifting and contested social and political spatial processes linked to particular political projects rather than just territorial 
lines (Houtum \& Et. al., 2005). However, these borders and boundaries are not just a top-down macro social and state policies but are present in everyday discourses and practices of different social agents, from state functionaries to the media to all other differentially positioned members of society (Yuval-Davis et Al. ., 2017 forthcoming). Everyday bordering has been developing a technology of control of diversity by governments which have been seeking to supposedly reassert control over the composition and security of the population. Instead of borders being on the point of moving from one state to another, borders have now spread to be everywhere. All citizens are required to become untrained unpaid border guards, and more and more of us are becoming suspects as illegal, or at least illegitimate border crossers. This has been a tendency that developed for quite a few years, probably since 9/11 if not before, but the 2014 and 2016 immigration Acts have clinched this. Now, every landlord, every employer, every teacher, every doctor, is responsible to verify that her or his tenants, employees, students, patients, are legally in the country and if they fail, they are legally responsible and might even go to prison for failing to do so (unlike those who are trained and paid to do this job). These UK Immigration Acts counteract the power devolution in Northern Ireland (and Scotland) in everyday lives.

In 1998, and with the Good Friday Peace Agreement, Northern Ireland became a devolved constituent region of the UK, and the devolved legislature of the Northern Ireland Assembly was established. Though constitutional and security issues are under the control of the Northern Ireland Office, the OFMDFM (Office of the First Minister and Deputy First Minister) and, for example, information about the number of asylum seekers arriving on the shore of Ireland, are under direct control of the Home Office. In effect, national security and border control are excepted matters of the central government in London (Westminster) which can produce tensions with the devolved matters of for example 'housing, health, education and employment'. Immigration control as an excepted matter complicates the role of governance and policy making for the Northern Ireland Executive. Following the Immigration Act 2016 the private rented sector actors are regarded as agents of immigration control. The consequences of this being that an immigration measure becomes a housing measure, as well as a licensing, social care and labour market measure. (Murphy \& Vieten, 2017)

Thus, from a convivial multi-cultural diverse society this technology of control is breeding suspicion, fear and sensitisation of the boundaries between those who belong 
and those who do not. Brexit has only enhanced this sense of differentiation and hierarchization among people.

\section{Autochthonic politics of belonging}

Peter Geschiere (2009) defined autochthonic politics as the global return to the local. It relates to a kind of racialisation that has gained new impetus under globalization and mass immigration and can be seen as a form of temporal-territorial racialization, of exclusion and inferiorization, that are the outcome of the relative new presence of particular people and collectivities in particular places (neighbourhood, region or country). The Greek word 'autochthony' (=to be of the soil) is used in the Netherlands and in the Francophone world, where the crucial difference is between the 'autochthones' who belong and the 'allochthones' who do not

Geschiere (ibid: 21-2) rightly claims that 'autochthony' can be seen as a new phase of ethnicity, although in some sense it even surpasses ethnicity (see also Yuval-Davis, 2011). While ethnicity is highly constructed, relationally and situationally circumscribed, there are limits to these reconstructions regarding name and history. Autochthony is a much more 'empty' and thus elastic notion. It states no more than 'I was here before you' and, as such, can be applied in any situation and can be constantly redefined and applied to different groupings in different ways. It combines elements of naturalization of belonging with vagueness as to what constitutes the essence of belonging, and thus can be pursued also by groups which would not necessarily be thought to be autochthone by others. The notion of autochthonic politics of belonging is very important when we come to understand contemporary populist extreme right politics in Europe and elsewhere. The people who follow these politics continuously argue that they are 'not racist', although they are very much against all those who 'do not belong'. As far as a pan-European discourse of far-right racist populism is concerned the national-territorial notion of autochthony adopts also another layer of trans-national culturalism; a myth of European 'Christian cultural heritage' (Vieten, 2016: 624). For example, in the Dutch context the social categories of 'autochthon - allochthon' framed ${ }^{\mathrm{vi}}$ policy, academic research and political debates since the 1970s, and by doing so racialise(d) (Yanow \& Van der Haar 2013; Essed \& Hoving 2014; Jones 2014; Vieten 2016) post-colonial visible minorities as well as migrant newcomers to the society, particularly Surinamese-Dutch and Moroccan-Dutch. In some cases, such as in the case of the English Defence League in the UK, the organization has formally both Jewish 
and Gay sections, as well as Hindu, Sikh and Afro-Caribbean supporters, something unimaginable in the older kind of extreme right organizations with neo-Nazi ideologies. Geert Wilders and the Dutch PVV (Freedom Party) also have been noticeable for a 'pseudo' advocacy of women and gay rights (Vieten 2016). In France, Marine Le Pen who is the current leader of Front National, originally led by her father, goes to great lengths to deny that her party is racist, anti-Semitic or homophobic. Marine Le Pen claims that 'the right-left divide makes no sense anymore. Now the real division is between nationalism and globalisation'. Thus, she warns of the 'dilution' and 'wiping out' of the French nation and civilisation, under threat from 'never-ending queues of foreigners' (interview in the Guardian, 2011).

Autochthonic politics of belonging can take very different forms in different countries and can be reconfigured constantly also in the same places. Nevertheless, like any other forms of racialization and other boundary constructions, their discourses always appear to express self-evident or even 'natural' emotions and desires: the protection of ancestral heritage, the fear of being contaminated by foreign influences, and so on, although they often hide very different notions of ancestry and contamination.

\section{Brexit, everyday bordering and autochthonic politics of belonging}

As described above, both everyday bordering and autochthonic populist politics can be seen as forms of racialisation. The process of racialisation involves discourses and practices which construct immutable boundaries between homogenized and reified collectivities. These boundaries are used to naturalize fixed hierarchical power relations between these collectivities. Any signifier of boundaries can be used to construct these boundaries, from the colour of the skin to the shape of the elbow, to accent or mode of dress. (Anthias \& Yuval-Davis, 1992; Murji \& Solomos, 2005).

Racialisations have ultimately two logics - that of exclusion, the ultimate form of which is genocide, and that of exploitation the ultimate logic of which is slavery. However, in most concrete historical situations these two logics are practiced in a complementary way. Since the 1980s there has been a lot of discussion on the rise of what Barker (1982) called 'the new racism' and Balibar (2005) 'racisme differentialiste'. Unlike the 'old' racism, the focus of these kinds of racialization discourses focused not on notions of 'races' or of other kinds of different ethnic origins, but on different cultures, religions and traditions which were seen as threatening to 'contaminate' or 'overwhelm' the 
cultural 'essence' of 'the nation'. It links to what Ghorashi $(2007 ; 2010)$ calls 'culturalism', or Vieten calls 'gendered culturalism' (Vieten 2016).

Everyday bordering links racialisation formally to citizenship status, but underlying this is a mythical nostalgic imaginary in which all citizens are members of the nation, and the boundaries of civil society overlap the boundaries of the nation as well as the state. This is the same logic as that of autochthonic populism in which only those who 'belong' should have access to state and other social, economic and political resources. These forms of racialisation exist in the context of neo-liberal globalisation and 'the age of migration', in which a variety of ethnic and racial communities have migrated and settled, constructing pluralist multicultural societies and citizenships. This is especially true, of course, in the context of the EU, but has also characterised the relationship of Ireland and the UK for a much longer period. It is for this reason that many contemporary populist imaginaries, as we have seen above, have incorporated some of this social heterogeneity as long as that social heterogeneity does not threaten hegemonic political projects of belonging and thus, they can claim of 'not being racist'. Indeed, David Goldberg (2015), has linked the spread of the 'postracial society' notion as the logic and condition that enables racism to persist and proliferate.

\section{Conclusion}

This paper has argued that that Brexit should be analysed in the context of people and governments' reactions to 'the double crisis of governability and governmentality' (Yuval-Davis 2012). Geschiere's (2009) claim that the concept of 'autochthony' characterises a new phase of community boundary drawing complementing the concept of ethnicity is applied to the UK context, and further illustrated while discussing some relevant emanations of this development and also distinctions as far as Northern Ireland, the Netherlands and France, for example, are concerned. The 2016 election of the US president Trump, and his country-selective ban of Muslim immigrants and refugees entering the US, adds another layer of complexity to this autochthonic political of belonging as it is evolving.

It is for this reason of a shifting project of autochthonic politics of belonging that some members of racialised minorities who have settled in the UK, especially those who arrived before the 1981 Nationality Act and were, as coming from countries that used to be part of the British Empire. Back then they were entitled for automatic right to settle 
and gain UK citizenship. This identification and feeling of belonging to the UK might have influences some to vote for Brexit, feeling that in the Brexit political project of belonging they can belong more than in the EU political project, in which they saw themselves as racialised outsiders.(Vieten 2018, forthcoming) They could thus join the Brexit autochthonic political project of belonging. Many of them, of course, were bitterly disappointed, with the sharp rise of racist attacks after Brexit towards all racialised minorities.

The motivation of some members of settled racialised minorities in the UK to vote for Brexit is just one particular situated motivations that brought people to vote for Brexit from different sections of British society and this is why a situated intersectional analysis (Yuval-Davis, 2014; but see also Crenshaw, 1991; Vieten 2009; Lutz \& al, 2011; Hill-Collins \& Bilge, 2016) is so central in examining social, political, cultural and economic relations. However, the overall implications regarding the effect of Brexit on the relationships between identity, citizenship and the state, has been to highlight and sensitise the boundaries of national citizenship and belonging, excluding all those sections of society who do not carry British passport as well as those the racist imagination would like not to be entitled to.

\section{References}

Anthias, F. and Yuval-Davis, N., 2005. Racialized boundaries: Race, nation, gender, colour and class and the anti-racist struggle. Routledge.

Archibugi, D., Held, D. \& D. Koehler (1998), eds. Re-imagining Political Community: Studies in Cosmopolitan Democracy, Stanford University Press, California.

Balibar, E. (2005) Difference, otherness, exclusion. Parallax, 11(1), pp.19-34.

Barker, M. (1982) The new racism: conservatives and the ideology of the tribe.Barth, F. (1998), Ethnic groups and boundaries: The social organization of culture difference. Waveland Press.

Beck, U. (2003). 'Toward a New Critical Theory with a cosmopolitan intent', Constellations 10, 453-468.

Beck, U. and E. Grande (2007). Cosmopolitan Europe. Cambridge: Polity Press Bauman, Z. (2007). Consuming Life. Cambridge: Polity Press. 
Bell, Ch. and McVeigh, R. (2016). A Fresh Start for Equality? The Equality Impacts of the Stormont House Agreement on the "Two Main Communities" - An Action Research Intervention', Equality Coalition, Dublin

Castles, S. and Miller, M.J. (2003), The age of migration: International population movements in the modern world, Basingstoke: Palgrave.

Cheah, P. \& B. Robbins, eds. (1998). Cosmopolitics: Thinking and Feeling Beyond the Nation, London: University of Minnesota Press.

Cohen, S.D. (2007). Multinational corporations and foreign direct investment: Avoiding simplicity, embracing complexity. Oxford University Press.

Crenshaw, K. (1991) Mapping the margins: Intersectionality, identity politics, and violence against women of color. Stanford law review, pp.1241-1299.

Eichenberg RC, Dalton RJ (2007) Post-Maastricht blues: The transformation of citizen support for European integration, 1973-2004. Acta Politica 42(2-3): 128-152.

Essed, Ph. and Hoving, I., eds., (2014). Dutch Racism. Amsterdam: Rodopi.

Fukuyama, F. (1992). The end of history and the last man, Free Press

Geschiere, P., 2009. The perils of belonging: Autochthony, citizenship, and exclusion in Africa and Europe. University of Chicago Press.

Ghorashi, H., (2010). 'Culturalist Approach to Women's Emancipation in the Netherlands.' In: H. Moghissi and H. Ghorashi, eds. Muslim Diaspora in the WestNegotiating Gender, Home and Belonging. Farnham: Ashgate, 11-22.

Goldberg, D.T. (2015), Are we Postracial yet?, Cambridge: Polity Press

Guardian, (2011), Interview with Marine Le Pen, 22 March (Link?)

Hill-Collins, P. and Bilge, S. (2016) Intersectionality. LOCATION? John Wiley \& Sons.

Houtum, H. van, Kramsch, O \& Zierhofen (2005) (eds.) Bordering space [prologue 113], Aldershot: Ashgate.

Hutton, W. (2012), Presentation in the Guardian Panel on Capitalism, 16.4. (link?)

Jarman, N. and Monaghan, R. (2003). Racist Harassment in Northern Ireland. Available at 
http://www.conflictresearch.org.uk/publications.php

Jones, G., 2014. Just Causes, Unruly Social Relations. Universalist-Inclusive Ideals and Dutch Political Realities. In: U.M. Vieten, ed. Revisiting Iris Marion Young on Normalisation, Inclusion and Democracy. Basingstoke: Palgrave Macmillan, 67-86.

Lutz, H., Herrera Vivar, M.T. \& Supik, L. (2011), (eds.), Framing Intersectionality, Farnham: Ashgate

Marshall, T.H. (1950), Citizenship and social class, Cambridge: Cambridge University Press

Marshall, T.H. (1975), Social Policy in the Twentieth Century (1965), London: Hutchinson

Marshall, T.H. (1981), The Right $t$ Welfare and other essays, London: Heinemann.

McGarry, J. \& O’Leary, B. (2006). 'Consociational Theory, Northern Ireland's Conflict, and its Agreement. Part 1: What Consociationalists Can Learn from Northern Ireland.' In: McGarry, J. \& O’Leary, B. (2006). Government and Opposition. Oxford; Balckwell Pubisher, 43-63.

Murji, K. and Solomos, J., 2005. Racialization: studies in theory and practice. Oxford University Press on Demand.

Murphy, F. \& U. M. Vieten (2017) Asylum Seekers and Refugees Experiences of Life in Northern Ireland. Final report to the OFMDFM, Stormont. Belfast, 2017.

Murphy, R. (2011). The Courageous State: Rethinking Economics, Society and the Role of Government, Searching Finance.

Pattison, J. (2010). 'Deeper objections to the privatisation of military force'. Journal of Political Philosophy, 18(4), 425-447.

Sassen, S., (2015). Losing control?: sovereignty in the age of globalization. Columbia University Press.

Schiek, D. (2012). Economic and Social Integration: The Challenge for EU Constitutional Law. Cheltenham: Edgar Elgar Publisher. 
Schiek, D. (2016). 'A Constitution of Social Governance for the European Union'. In: D. Kostakopoulou \& N. Ferreira (eds.) The Human Face of the European Union: Are EU Law and Policy Human enough?, Cambridge: Cambridge University Press. 17-47. Schierup, C.U., Hansen, P. and Castles, S., (2006). Migration, citizenship, and the European welfare state: a European dilemma. Oxford University Press on Demand.

Vieten, U.M. (2007). Situated Cosmopolitanisms: the notion of the Other in discourses on cosmopolitanism in Britain and Germany, $\mathrm{PhD}$ Thesis, University of East London (UK).

Vieten, U. M. (2009). 'Intersectionality scope and multidimensional equality within the European Union: Traversing national boundaries of inequality?' In: D. Schiek \& V. Chege (eds.) European Union Non-Discrimination Law: Comparative Perspectives on Multidimensional Equality Law, London/New York: Routledge-Cavendish, 91-114.

Vieten, U.M. (2012). Gender and Cosmopolitanism: A Feminist Perspective. Farnham: Ashgate.

Vieten, U. M. (2016). 'Far Right Populism and Women: the Normalisation of Gendered anti-Muslim Racism and Gendered Culturalism in the Netherlands', Journal of Intercultural Studies, 37:6, 621-636.

Vieten, U. M. (2018). "'Europe is for being recognized for more than an ethnic background": British, Dutch and German minority activists' perspectives on racism, European citizenship and belonging', Cosmopolitan Civil Societies: An Interdisciplinary Journal, 10 (1), 27-45.

Yanow, D. and van der Haar, M., (2013). 'People Out of Place: Allochthony and Autochthony in the Netherlands' Identity Discourse - Metaphors and Categories in Action.' Journal of International Relations and Development, 16, 227-261.

Yuval-Davis, N. (2011). The Politics of Belonging: Intersectional Contestations, London: Sage

Yuval-Davis, N. (2012). 'The double crisis of governability and governmentality', Soundings, no 52:88-99

Yuval-Davis, N. (2014). 'Situated Intersectionality and Social Inequality' in Raisons Politiques no. 58:91-100 
Yuval-Davis, N., Wemyss, G. \& Cassidy, K. (2016). 'Changing the racialised "common sense" of everyday bordering', Open Democracy, 17 February, 2016

Yuval-Davis, N., Wemyss, G. \& Cassidy, K. (2017, forthcoming). Bordering, Cambridge: Polity Press

\footnotetext{
${ }^{\mathrm{i}}$ http://www.lisbon-treaty.org/wcm/the-lisbon-treaty/treaty-on-European-union-and-comments/title-6-finalprovisions/137-article-50.html

iii http://www.balkanalysis.com/blog/2004/02/17/problems-of-consociationalism-from-the-netherlands-tomacedonia/

iviv It is not possible to elaborate this complexity here; a separate chapter or paper is needed to look at the different layers of colonialism, racism and sectarianism in Northern Ireland.

${ }^{v}$ https://www.theguardian.com/politics/2017/jan/09/martin-mcguinness-to-resign-as-northern-ireland-deputyfirst-minister
}

${ }^{\text {vi }}$ Only in March 2016, the Dutch parliament decided to review and abandon the terminology (Vieten 2016). 